\title{
Entrevista con Carlos García Gual
}

Ensayista y reconocido estudioso del mundo antiguo, Carlos García Gual -nacido en Palma de Mallorca en 1943-, es catedrático de griego en la Universidad Complutense de Madrid, tras haber sido profesor en Granada y Barcelona, y en la UNED. Pero sobre todo este ávido lector se formó en Madrid con helenistas de la talla de Manuel Fernández Galiano, Francisco Rodríguez Adrados y Luis Gil, se aventuró pronto en el conjunto del legado clásico y en la literatura comparada, así como en el impulso editorial, pues ha sido capaz de desarrollar un sinnúmero de iniciativas para mantener viva la herencia griega.

Sus publicaciones se iniciaron en los setenta con un volumen de erudición filológica redactado antes, en 1966: El sistema diatético en el verbo griego. Pero su trabajo profesional se percibe mejor en sus futuras recopilaciones sobre la filosofía clásica o helenística, su prólogo a La ciudad antigua de Fustel de Coulanges y a algunas tragedias de Eurípides, o su Antología de la poesía lírica griega (siglos VII-IV $a$. C.). Asimismo en esa línea, que ha definido la parte fundamental de su carrera, hay que considerar sus numerosas introducciones al pensamiento griego, como el Anábasis de Jenofonte; a ciertos diálogos de Platón, que él tradujo; a la Política y la Investigación sobre los animales de Aristóteles; a los Tratados hipocráticos, algunos de los cuales asimismo tradujo; o a las Meditaciones de Marco Aurelio. Pero también a relatos antiguos como la Vida de Alejandro, El viaje de los argonautas, Quéreas y Calírroe, Calímaco y Crisórroe, Dafnis y Cloe, o a las Fábulas de Esopo, que han sido fuente de sus análisis futuros. Hay que considerar además dos importantes versiones suyas aparecidas hace poco: su admirada Odisea y las Vidas de los filósofos de Laercio, que tanto ha utilizado.

Además de esta visión del pasado, que Los orígenes de la novela sintetiza, pronto entró a narrar las vicisitudes del relato occidental desde sus inicios con Primeras novelas europeas, de modo que irá combinando siempre sus trabajos sobre Grecia con estudios sobre la novela artúrica o sobre la novela histórica más o menos reciente. Así publica, por un lado, Prometeo, mito y tragedia, un penetrante Epicuro en 1981 (el libro del que se siente más orgulloso), o sus amenos La secta del perro, sobre los viejos cínicos, y Mitos, viajes y héroes; pero, por otro, la Historia del rey Arturo y de los nobles y errantes caballeros de la tabla redonda -él compartió una versión de Lanzarote del Lago de Chrétien de Troyes-, El redescubrimiento de la sensibilidad en el siglo XII, así como la recopilación Lecturas y fantasías medievales.

García Gual ha reflexionado por añadidura sobre el pensamiento mítico en tres trabajos: La mitología; una Introducción a la mitología griega; y su divulgado Diccionario de mitos. Por otra parte, hay que contar con ensayos de distinto tipo sobre Grecia: Los siete sabios (y tres más), alejado de la solemnidad; Figuras helénicas y géneros literarios, que acoge parte de su trabajo introductor; Audacias 
femeninas, sobre un quinteto de mujeres antiguas; o El zorro y el cuervo, donde rastrea ese motivo esópico. Además, están tres libros sobre el arte del relato: Apología de la novela histórica; Viajes a la Luna; La Antigüedad novelada. A todo lo cual se suman dos volúmenes singulares: los artículos Sobre el descrédito de la literatura y otros avisos humanistas (1999), donde aparece el tema que le da título, y su reciente Historia, novela y tragedia, que es una suma cuidadosa de los temas clásicos que ha abordado en su vida. En conjunto, aunque se surtan a veces de ellos, todos esos libros compiladores no llegan a recoger los centenares de artículos y reseñas de libros publicados con su firma en revistas y obras colectivas.

Finalmente, García Gual es director de la sección griega de la Biblioteca Clásica Gredos (=BCG), que ha supuesto un verdadero hito en la cultura española de los últimos treinta años (la serie va acercándose a los 400 títulos); y también ha dirigido la colección de la Biblioteca Universal de esa misma editorial (con cerca de cincuenta títulos).

\section{¿Sigues vinculado a Palma de Mallorca?}

Cuando murieron mi abuelo y mi tía perdí una referencia familiar importante; desapareció además la casa donde yo nací, que tenía una buena biblioteca. Voy dos o tres veces al año a dar charlas o a pasar unos días a Mallorca. Me quedan pocos amigos, pero tengo aún una hermana allí. Me siento, en cambio, vinculado al paisaje, de mar y pinos, y también a la ciudad de Palma. Eso sí, aunque mi abuelo materno y toda su familia eran mallorquines, vengo de una familia muy mezclada, y el sentimiento de pertenencia al campo, a la tierra o incluso al mar es más liviano. Mi abuelo mallorquín se casó con una madrileña y mi padre era hijo de un veterinario de Tierra de Campos, en la provincia de Palencia. Venía de una familia de médicos y veterinarios, y de algún ingeniero militar burgalés, que fueron bajando, unos hasta San Cebrián donde vivía mi abuelo, otros hasta Valladolid, donde viven algunos primos míos.

\section{El mundo religioso parece ajeno a ti.}

Soy poco religioso, en efecto. Mi padre no lo era ni tampoco mi abuelo. De pequeño iba, lo recuerdo con cariño, con mi abuelo a las misas a la catedral de Palma de Mallorca, y nos sentábamos en los primeros bancos; pero creo que a él le gustaba sobre todo la liturgia en medio del esplendor gótico y luminoso. Las mujeres de mi familia lo eran un poco más, aunque sin excesos devotos; más bien eran simples cumplidoras de los habituales ritos. Tampoco soy antirreligioso. Nunca me ha atormentado la angustia religiosa... Creo que eso lo he heredado de mi familia. Además estudié el bachillerato en institutos y en instituciones públicas. Se me debía de notar mi incredulidad, o mi talante escéptico, porque creo 
SALUD MENTAL Y CULTURA

recordar que en los ejercicios espirituales, tan aburridos, a los que tuve que acudir de niño, nunca intentaron convencerme de nada.

Nos gustaría que nos resumieras tu formación.

Yo estudié algunos cursos en el Instituto de Enseñanza Media de Figueras y luego en el de Palma de Mallorca. Pero la carrera Universitaria la hice en Madrid. Aquí vine a estudiar Filosofía y Letras: fueron dos años de comunes seguidos de tres de la especialidad de clásicas. Tuve mucha suerte. Tuve de maestros a grandes profesores de lenguas clásicas. Algunos de ellos, ya jubilados, siguen escribiendo todavía, por ejemplo Rodríguez Adrados o Luis Gil. En cambio, han desaparecido Fernández Galiano y Laso de la Vega. Los profesores de latín -García Calvo, Mariné o Tovar- me han marcado menos, quizá porque los tuve solo un año y me dediqué más al griego. Ahora los estudiantes se inclinan antes por una u otra especialidad, pero en mi tiempo había un claro paralelismo entre las asignaturas de griego y latín. A mí me gustaba desde siempre más el griego, con todo su trasfondo cultural, y además, en conjunto, eran más interesantes los profesores de esta lengua.

\section{¿Cómo saliste al extranjero por esos años difíciles?}

Salí, por mi cuenta y riesgo, al extranjero, al margen de los estudios de la carrera. Recuerdo un curso de alemán en Viena, mensual, cuando estudiaba quinto año. También estuve en Maguncia, al año siguiente. Luego, viajé libremente por distintas ciudades, asistí a algunos coloquios y presenté mis ponencias, pero no estuve vinculado a ninguna universidad. Es muy diferente a lo que hace la gente ahora, que suele acudir muy a menudo a reuniones en el extranjero y establece más vínculos. Acabo de participar en un tribunal para las habilitaciones a cátedras, y los candidatos tenían veinte o treinta comunicaciones internacionales. Eso no sucedía por entonces... En realidad, no creo andar muy dotado para el manejo práctico de los idiomas; los leo mejor que los hablo. Sin duda, es por mi formación inicial, la de mi generación; yo estudié francés, que es la lengua en la que me desenvuelvo bien. Luego, he sido muy autodidacta con el alemán y con el italiano, que empleo con cierta soltura. Leo con facilidad el inglés, pero lo hablo con torpeza; y eso es hoy un grave defecto. Hoy se suelen estudiar dos o tres idiomas desde muy pronto; mi hija (que es la nueva traductora de Thomas Mann) habla muy bien tanto alemán como inglés y francés.

Te inicias como profesor en un Instituto madrileño, luego en la Universidad de Granada (en donde acaso conocieras al galénico García Ballester), y en la de Barcelona.

Fui catedrático del Beatriz Galindo de Madrid; en ese Instituto clásico estuve durante cuatro años, hasta 1972. Recuerdo sus aulas con mucho cariño. Acababa de 
licenciarme -en 1965- y de presentar la tesis -en 1968-, que se publicó en 1970, sobre las voces del verbo griego. En aquella época muchos profesores de Universidad lo fueron antes de Instituto. Incluso había entonces muchos profesores de Instituto tan notables como los de Universidad: llegué allí un poco antes que Domínguez Ortiz; también estuvieron Luis Gil y el geógrafo Terán. Yo sustituí a Fernández y Ramírez, que redactó una excelente Sintaxis del Español para la Academia. Era un centro con mucha solera, y con alumnas muy inteligentes. Después estuve un año de agregado en la Universidad de Granada; no sé si coincidí en el tiempo con García Ballester, al que traté muchos años después, en Madrid, porque él estaba en Medicina y había pocos contactos. No tuve muchas relaciones; la sociedad granadina me pareció muy cerrada. Pronto, ya de catedrático, pasé a la Universidad de Barcelona.

Has dicho una vez que evitas la jerga y el disfraz profesional. Parece que tiendes también a huir de las teorías o que prefieres usar categorías intermedias de análisis.

Nunca me han interesado mucho ni la vida académica ni sus cargas y cargos; las tramas y mecanismos para escalar me desagradan... La teoría por la teoría me gusta, y las ideas generales me atraen, pero no me seducen las ortodoxias de una u otra escuela. He ido un poco por libre. Hice mi tesis sobre lingüística porque en Madrid los profesores de griego eran sobre todo lingüistas, pero la escribí sin una entrega absoluta, pese a ser un momento muy favorable y brillante de ese campo. Por ejemplo, leí a Benveniste con mucho interés (su trabajo sobre el indoeuropeo es deslumbrante) y admiré mucho a un estudioso de la fonética estructural como A. Martinet, relacionado por cierto con la escuela de Madrid; pero no me encontraba cómodo dentro de un esquema muy rígido. A mí me gustaba la lingüística; pero también la cultura, así que mis libros están escritos un tanto al margen de lo que es usual en los círculos de aquella Universidad.

\section{¿Te identificas con alguna corriente de pensamiento?}

Me atrajo mucho la mirada estructural, aunque no la más estricta. A veces practicaba un estructuralismo más abierto, más funcional, diría ahora, como el que utilizaba Adrados en Madrid, donde no se oponía de modo rígido la sincronía a la diacronía, sino que se enfocaba lo sincrónico como resultado de una vivaz evolución diacrónica. Al fin y al cabo, si aún enjuicio antes el esquema general de las cosas que las particularidades, en parte creo que es debido a la influencia estructuralista que recibí... La interpretación filosófica puede y suele ser más parcial, mientras que al filólogo le queda un mayor margen de imparcialidad, se ve menos comprometido con una doctrina específica. Como filólogo me interesan, desde luego, las ideas (procuro huir del excesivo detallismo), pero me disgustan los ámbitos cerrados y los dogmatismos escolares. 
SALUD MENTAL Y CULTURA

¿Prefieres la mirada positivista histórica o más bien la hermenéutica?

Soy bastante ecléctico. Respeto las oposiciones conceptuales cuando son fructíferas. Por ejemplo, los mitemas o unidades míticas que buscó Lévi-Strauss para ver sus combinaciones y transformaciones sirven para centrarse en el material mítico y para relacionar luego también su significado en la cultura y la sociedad, aunque le conducen a ciertas ideas incontrastables sobre la mente y su funcionamiento. He seguido también a otros autores, como Cassirer, Dumézil, Kirk o Vernant, pero tiendo a contar siempre con el contexto histórico. Así, por ejemplo, para estudiar la novela creo que tanto las ideas de Lukács como las precisiones de Duby son muy útiles. No he sido un formalista ni tampoco un historicista ligado a los pequeños detalles. Tiendo a mezclar los géneros: la literatura con la filosofía. Me gusta observar las ideas dentro de los textos y la expresión literaria dentro de los pensadores.

No me adscribiría a ningún movimiento de conjunto; pero la hermenéutica, por ejemplo, me interesa también mucho. En particular, la lectura de Gadamer me atrajo en su momento; ahora me resulta un autor algo nebuloso, con una retórica demasiado amplia para mí. Así que enseguida vuelvo a lo histórico y, en especial, a los ejemplos significativos; los antepongo a las ideas generales, que aprecio sin duda como se ve por ejemplo en mis libros sobre mitología.

Vayamos a tu obra, empezando por la novela antigua. La figura de Alejandro Magno que has elegido es novelesca.

$\mathrm{Si}$, yo traté el Alejandro más novelesco, pasando de la historia al mito a través de la leyenda. La Vida de Alejandro de Pseudo Calístenes, cuya única traducción aún es la mía, encabezó la colección clásica de Gredos en 1977. Hubo un poco de «trampa»: como yo dirigía la serie decidimos iniciarla con algo original; después ya vinieron Heródoto o Platón, pero queríamos indicar de antemano que no se limitaría a lo esperable... También Los orígenes de la novela, de 1972, fue el primer libro de bolsillo sobre ese aspecto. Hubo gente que pensaba que sería muy abstruso para una edición popular, pero se vendió muy bien. Esa «biografía» o las novelas griegas era un terreno casi virgen entonces, pero hay una bibliografía tremenda y exhaustiva ahora.

Sí, me gustan las figuras con originalidad personal o ideológica. Me atraen los textos que tienen cierta novedad... Me gustaría ser cronista de algunas vidas, como la de Alejandro, aunque ya es imposible porque existen centenares de biografías. Tampoco sé si hubiera tenido la paciencia de investigar como hacen los biógrafos ingleses, que siguen al personaje en su largo recorrido por el paisaje y las épocas, con minucia y buen estilo. Siempre he admirado su lectura directa y meditada de los originales, sus comentarios críticos precisos, su atención al contexto. 
Dominan las anécdotas en los Siete sabios, en tus libros sobre los cínicos o sobre Esopo.

Es verdad, me intereso por las anécdotas, siguiendo en esto a Diógenes Laercio, y también a Montaigne o a Nietzsche, que lo admiraban. Pero es que según creo las anécdotas son muy reveladoras; a través de ellas se percibe a veces mejor la conexión entre una idea y la realidad. En este aspecto creo que soy un filólogo tradicional (o antiguo, no sé), casi como los alemanes del siglo XIX, que cultivaban «la ciencia de la Antigüedad», la Altertumswissenschaft. No soy un lingüista puro, ni tampoco un historiador, ni un filósofo, sino una mezcla de todo, un bricoleur acaso. Me salgo un poco por la tangente de las escuelas, clásicas o hispanistas. Me ha perdido siempre la curiosidad; eludo estrujar los mismos temas. Intento ser riguroso en mis trabajos, pero me atraen los filósofos marginales o maltratados, como Epicuro o los cínicos, del mismo modo que en literatura prefiero las figuras mixtas, a veces criticadas. Cuando traduje El viaje de los argonautas de Apolonio de Rodas no se estudiaba ese texto en nuestras aulas clásicas, pues se le tomaba por un autor helenístico tardío; hoy la mirada se ha ampliado.

\section{En los años sesenta reaparece Nietzsche en Europa, pero lo citas de un modo personal.}

No soy un nietzscheano, pero sí un lector de Nietzsche desde muy joven. Sus obras estaban en la biblioteca de mi abuelo, en una de esas primeras traducciones al español de finales del siglo XIX, seguramente aisladas: Ecce homo, Así hablaba Zaratustra. Siempre me fascinó su figura. En él estaban las ideas de las que hablamos, el estilo brillante, la sugerencia, la crítica de la realidad y también de la tradición filosófica. He escrito tres o cuatro artículos sobre el Origen de la tragedia en el espíritu de la música, pero nunca he sido un estudioso a fondo de su obra.

Me atrae la vida de Nietzsche, su peripecia trágica, en parte marcada por la herencia familiar, que incluye acaso la locura. Me parece muy significativo el hecho de que, cuando era catedrático en Basilea, la persona a la que más admiraba fuese a Jacob Burckhardt, un gran patriarca de la ciudad e hijo de un obispo protestante. El gran historiador, un hombre ilustrado, nunca le correspondió ni le reconoció lo suficiente; es como si sintiera recelo ante un genio que no se sujeta a las normas. En algunas cosas quizá Burckhardt tuviera razón: detestaba la música de Wagner, a quien Nietzsche idolatró al inicio, y prefería a Mozart y los clásicos alemanes. Es curioso que Nietzsche buscara la aprobación que nunca encontró en Burckhardt, aunque éste no dejaba de percibir su genialidad. Son aspectos algo mezquinos de la vida académica. Como todo personaje único tendía a quebrar las normas; por su lado irracionalista fue un marginal, que sólo tardíamente logró admiradores. Su genio se le reconoció a fondo ya desaparecido de escena. 
SALUD MENTAL Y CULTURA

Para mí es una pasión personal. He leído ensayos muy interesantes sobre sus ideas, pero me gusta sobre todo leerlo a él. Y releerlo a menudo. A veces abro uno de sus libros, leo unas cuantas páginas, reconozco pasajes. Hace poco seguí los aforismos que Sánchez Pascual publicó en Edhasa, con gran acierto y sensibilidad. Y releo con frecuencia sus fragmentos sobre el mundo griego. Siempre es muy agudo; hoy acaso podemos apreciar algunos errores, como dice la crítica reciente, pero su perspectiva ha marcado nuestra visión sobre los griegos.

Ya nadie cree en el milagro griego, en una oposición total entre el mito y la razón; has escrito que «los mitos tienen su manera de explicar el mundo, aunque recurren para ello a un lenguaje simbólico que no es el del logos; también la razón apela a los mitos». Vernant lo corroboró modernamente al exponer cómo el hombre griego se «fabricó» a sí mismo a través de su cultura; exploró la organización del espacio y de las distintas temporalidades; fue elaborando diversos tipos de lógica en la narración o la historia, en la política o la filosofía, en la demostración matemática o el tratado médico.

El rechazo a la rotundidad del «milagro griego» se encuentra en muchos pensadores, historiadores y filólogos del siglo pasado. Ese ideal helénico suena mucho a siglo XVIII, a Renan y su Plegaria sobre la Acrópolis, y tantos escritores decimonónicos. Un gran crítico de esa idea fue Dodds en Los griegos y lo irracional, en los años cincuenta. La escuela de Vernant ha enseñado a rastrear bajo los textos muchas connotaciones y a utilizar con especial precisión las referencias históricas que estaban ya en el propio lenguaje y en los textos de ideas antiguos. Se trata de una hermenéutica influida por la psicología, la antropología y también el estructuralismo, que ha hecho ver que el mensaje griego era mucho más complejo y rico en matices de lo que proclamaba la beatería por los textos clásicos o la filología más plana y más retórica. No es tanto una crítica del «milagro» sino una visión más clara de la diacronía y de los textos. Ha roto además los límites que había entre filología, filosofía y crítica textual. Nos ha ayudado a ver con más profundidad y más gradaciones todo lo griego, desde la época arcaica hasta el mundo clásico. Si se ha ocupado menos de la época tardía del helenismo es porque ha ido a las raíces.

¿Los filósofos antiguos eran unos experimentadores del mundo interior, mediante sus ejercicios reflexivos, según estudió Pierre Hadot?

De Hadot conozco algunas cosas. Me ha interesado mucho su libro sobre Los ejercicios espirituales y la filosofía antigua. La filosofía era entendida no solo como una forma de pensar sino también como un modo de vivir; el modo filosófico era una práctica personal unida al ejercicio del pensamiento, suponía cierta transformación. Creo que así sucedía en el mundo antiguo, es muy propio del 
modo griego, lo retrata verdaderamente. Así que un catedrático de filosofía no es un filósofo en ese sentido de vivir de acuerdo con unas determinadas ideas; no es lo mismo un Platón, que vive en un círculo de amigos de ideas afines, que un Kant, que disocia mucho más su vida diaria de su actividad como pensador. La piedad antigua tenía además un papel muy reducido en la vida de los filósofos griegos... Con el cristianismo todo cambia, pues incorpora la piedad cristiana o mejor la vida religiosa como sustituto de la vida filosófica. Y entonces esa forma antigua de entender la existencia lentamente desaparecerá.

¿Tendría que ver con otra transformación? En la épica no hay una concepción decidida de cuerpo y alma. El cuerpo corre, actúa o piensa, pero se reduce a una serie de funciones, como has dicho una vez; el alma es un fantasma que se desprende con la muerte. Luego, los hipocráticos conciben el cuerpo como lo que ha de restaurarse, para que vuelva a su naturaleza saludable. En los siglos v y IV con Sócrates y Platón surge la idea del cuidado del alma, que sería lo fundamental del individuo: un espíritu duradero que hay que cuidar. ¿Tiene que ver, pues, con una transformación moral y ética?

Sin duda alguna; y tiene que ver también con el individualismo posterior. El hombre griego más antiguo estaba subordinado a la sociedad. El epicureísmo y el escepticismo rompen con esta dependencia, y refuerzan la idea de que son ellos responsables de su vida. Tras esa ruptura, el filósofo adopta una estética y una praxis conforme con su doctrina, como los epicúreos y estoicos. Muchos aspectos continúan en el cristianismo, como los ejercicios de conciencia que provienen de la filosofía griega. Con menos rigor lo encontraremos después en ciertos humanistas, como Ficino, que llevan una vida especial al modo de filósofos antiguos, al unir una ascética vital con una manera de pensar. Incluso, aunque de forma más mitigada, sucede en el mismo Montaigne, cuya reflexión es tan original como alejada de todo profesionalismo.

Vayamos a la historia. ¿Opones la visión más plural y subjetiva de Heródoto a la objetividad de Tucídides? ¿Te parece más moderno Heródoto, pese a su rechazo a pueblos como los escitas? ¿Los cronistas de Indias fueron recuperadores de su modo de hacer?

Esa recuperación del prestigio de Heródoto gracias, indirectamente, a los cronistas de Indias, en los siglos XVI y XVII, es una idea apuntada por Arnaldo Momigliano: en La historiografía griega habla de Pedro Mártir, de López de Gómara, de Oviedo. Heródoto fue tomado durante mucho tiempo por un mentiroso. Pero los historiadores del Quinientos investigaron la sociedad (historia significa 'investigación') fundiendo las miradas histórica y antropológica, de suerte que ayudaron a recuperar su prestigio. Admiro tanto el estilo de Heródoto como el de Tucídides, pero creo que éste -al 
SALUD MENTAL Y CULTURA

reducir la historia al mundo de la guerra, la política y el poder- restringe demasiado el enfoque, mientras que la visión humanista del primero le conduce a una concepción trágica de la naturaleza humana y de la historia.

Del «bárbaro» escita, por otra parte, sabríamos muy poco sin los textos herodoteos. En recientes estudios sobre los escitas y el Mar Negro, se recogen aspectos que ya había observado Heródoto, y se demuestra que eran verdaderos sus pintorescos apuntes; antes no estaba comprobado. Resulta más moderno ahora por su apertura a toda la sociedad y por la visión de los otros. Abre más la narración a otras voces y a la discusión, como sucede en historiadores más modernos (así Braudel). En el Alejandro Magno de Robin Fox Lane, traducido en 2007, se elogia también a Heródoto; y bajo su influencia va describiendo los paisajes y pueblos a medida que Alejandro avanza. Ha sido tachado injustamente de novelesco. Sus páginas sobre los elefantes en la Antigüedad son magníficas y me parecen un soplo de aire herodoteo. A Heródoto le hubiera gustado su análisis de los personajes o ese excurso de los elefantes en las guerras.

En La gaya ciencia Nietzsche pide hacer historias del amor, la codicia, la crueldad o la penalidad. Hoy la historia de la cultura ha analizado esos aspectos. Tú has reseñado obras de Peter Burke, quien destaca la historia del lenguaje, los viajes, el coleccionismo y las formas de lectura, o defiende una cultura material que incorpore aspectos simbólicos.

He admirado a Burke, un gran lector, por su riqueza de datos y su precisión. Sus diversas síntesis sobre el Renacimiento dan perspectivas agudas, y se complementan con magistrales monografías, como Los avatares de 'El cortesano', donde mezcla estética de la recepción e historia del libro. De hondo calado es Formas de historia cultural, sobre la nueva historia... Hace mucho me gustó El amor en Occidente de Denis de Rougemont; luego, diversos estudios sobre la amistad en Grecia. Hay aportaciones estupendas a la historia de los sentimientos morales, y buenos ensayos de microhistoria, como El queso y los gusanos de Carlo Ginzburg. Ya en la recopilación de Pierre Nora, Faire de l'histoire, muchos subrayaban toda esa amplitud de enfoques de la nueva historiografía. Y todos tendrían un lejano precursor en Heródoto, en donde lo histórico responde al discurrir de la vida... Algún parecido tienen esas historias de los inventos científicos que hay ahora, o de cómo ha marcado la vida la aparición de nuevos instrumentos. Habrá que ver en el futuro cómo se escribe la historia sobre la aparición de los teléfonos móviles, que han cambiado la sensibilidad y que obligan a la gente a pensar de un modo distinto.

Frente a la historia basada en las estadísticas sobre la producción y en la macroeconomía, hay otra historia narrativa, herodotea. La Historia de la vida privada de Duby es, por ejemplo, muy importante, pero ese acercamiento a lo coti- 
diano lo inició la novela histórica, lo habían intuido algunos románticos. En Los últimos días de Pompeya de Bulwer Lytton se insiste mucho en cómo vivía la gente. Soy un buen lector de historia, pero me gusta la que incluye lo humano, ese entorno antropológico. Los historiadores actuales han recuperado la narración amena; también los aspectos sociales y una visión compleja del mundo que plantee problemas nuevos.

El historiador Paul Veyne ha escrito en 2005 un grueso libro que trata solo de Roma, y lo titula El imperio greco-romano. Finley y Marrou señalaron que no hubo una educación ni desde luego una civilización autónoma romana propiamente dicha sino una adaptación sistemática de la educación helenística en la cuenca mediterránea. Incluso Veyne subraya que la originalidad del Imperio romano radicaba en su bilingüismo.

Siempre tuve a Paul Veyne por muy inteligente. Importantísimo fue El pan y el circo. Y su análisis del yo en el Satiricón [en La sociedad romana] es uno de los mejores que conozco sobre un texto novelesco, al mostrar cómo se entretejen sus personajes picarescos. También es muy sugerente, aunque complejo en su formulación, ¿Los griegos creían en sus mitos?

El bilingüismo, en el Oeste del Imperio, se refiere más a la alta cultura. Las personas cultas sabían griego desde muy pronto, tenían tutores griegos, les enseñaban su retórica. Y eso ocurría desde una época muy antigua, hasta cuando hubo ya una gran literatura latina; el griego era la lengua culta como lo podría ser el francés en la Rusia del siglo XVIII o del XIX, que se hablaba en las casas; ahora el mundo de las finanzas es inglés, no el cultural... Pero la primera historia de Roma que se redacta está escrita en griego. Y una figura como Marco Aurelio, que no tenía otra relación con Grecia que su educación (su familia es occidental, proviene de Galia e Hispania), recogió sus pensamientos más íntimos -si los escribía para sí mismo- en griego, acaso porque era la lengua de la filosofía. En la calle, el bilingüismo debía de ser más relativo. ¿Qué podía saber de griego un artesano o el público que acudía a una comedia de Plauto, quien por otro lado había sacado sus temas del mundo helénico? Habría además mucha diferencia entre casos como el de Adriano, que era un viajero y un filoheleno total, y el de Trajano, que era un militar hispano que sin duda no conocería el griego como él.

En tu introducción a los Tratados hipocráticos, dices que Aristóteles consideraba médico -iatròs- a todo investigador experto y también al hombre culto que hubiese leído sobre la ciencia de los médicos. ¿La medicina es un campo ecléctico que también te atrae?

De todos modos el verbo iao, significa 'curar', y el agente, iater, iatròs, es el 'curador'. Lo que subrayo es que el médico antiguo es alguien muy abierto y con 
SALUD MENTAL Y CULTURA

mucha cultura; es un tipo de médico que ha sido muy importante durante muchos siglos en Occidente -el médico de familia era cultivado y tolerante- y que ahora ha desaparecido con las especialidades y las máquinas. Como no había una traducción española completa de las obras hipocráticas, la impulsé y traduje los textos que más me gustaban, y dejé a otros los de detalles técnicos, como los ginecológicos. Me atraían el texto Sobre la dieta, con sus alusiones a la vida cotidiana, a los ejercicios y a la alimentación; y Sobre el médico, El pronóstico o Sobre la enfermedad sagrada. Son los libros más intelectuales de esos médicos que discutían de tú a tú con los filósofos porque se consideraban unos verdaderos profesionales del mundo real... Ahora están editados todos en ocho volúmenes de la BCG. Y por cierto Aristóteles, hijo de un médico macedonio, que tenía muchos libros de medicina, pensador inquieto, se planteó con mirada clínica los problemas del conocimiento del mundo real (y de las ciencias naturales en particular), y lo hizo con un lenguaje propio, con unos apuntes densos y vivos, alejados de toda receta y de toda rigidez, como comprueba quien lo lee para traducirlo con precisión.

Se ha resaltado que la ciencia griega no se tradujo al latín en la Antigüedad. Tampoco la medicina, y eso determinó que los nombres de las especialidades médicas sean griegas.

Eso ocurrió con la ciencia en general. Las palabras de la medicina, muchísimos médicos y lo que hoy llamaríamos científicos eran griegos. El mismo Galeno lo era aunque vivió mucho en Italia, en Roma. Fue por cierto el autor griego más fecundo, y se refirió siempre a los autores helénicos... Los médicos griegos fueron los primeros profesionales que hicieron una biblioteca, estuvieron en contacto con la gente, tuvieron una ética profesional bastante seria y se desvincularon de las prácticas religiosas racionalmente. Era una medicina ignorante si la vemos desde los cánones actuales, pero poseía un humanismo ejemplar (así se ve en el Juramento). Por eso tuvo tanto prestigio en el mundo grecorromano; hasta el emperador persa tenía médicos griegos. Sabemos poco de su farmacopea, bastante reducida eso sí. Conocemos que no eran muy dados a tratamientos drásticos; no hacían sangrías sistemáticas como en la Edad Media. Acompañaban al enfermo en su dolencia, orientaban la enfermedad hacia la salud. Para ellos la naturaleza era el modelo que había que seguir y ella significaba el límite de su intervención, mientras que la medicina moderna intenta mejorar lo natural, ir más allá. La idea de lograr un mejoramiento técnico de la naturaleza humana es ajena al pensamiento antiguo.

Has mostrado verdadera, quizá personal, predilección por Epicuro.

No sé si por sentirme algo pagano o epicúreo o escéptico. Me pareció que Epicuro tenía razón en muchas cosas. Seguro que hay una simpatía personal tam- 
bién, pues a alguien que no le interesa mucho el poder ni los cargos, obligatoriamente le cae bien un filósofo como él que defiende los pequeños placeres (la eliminación del dolor, la dicha suave), la amistad, o incluso ese jardín que yo nunca he tenido pero que me parece un buen ideal... Fue uno de los grandes pensadores del mundo antiguo. Epicuro no tenía la brillantez de Platón, desde luego, pero creó un sistema muy sólido. Defendía una especie de materialismo hedonista o de hedonismo materialista muy bien orientado; logró destacar la importante relación de los placeres del cuerpo y los del alma; para él son superiores los segundos aunque sean primarios los dolores del cuerpo. Partiendo de ideas anteriores, como el atomismo o la doctrina del placer de Aristipo, creó una teoría superior... Intenté subrayar cómo había sido maltratado en general por los historiadores de la filosofía, algo que se repite hoy. También en esto creo que me anticipé un poco a una cierta moda epicúrea bastante actual.

\section{¿Pesó también en el Epicuro tu aprecio por Diógenes Laercio y los eruditos tardios?}

Empecé ayudando a un amigo que escribía su tesis sobre Epicuro y Aristóteles. Me interesó como pensador y traduje sus textos, que son pocos, pues se perdió la obra muy pronto. También me ocupé de los cínicos, esos animadores de un movimiento intelectual en contra de las normas sociales, pero que no tienen la profundidad o la grandeza epicúreas. He traducido ahora por vez primera, en una colección de kiosco, unos fragmentos de Diógenes de Enoanda, un epicúreo tardío y menor, de mediados del siglo II; se empeñó en conservar textos de Epicuro, y lo hizo en una gran inscripción de más de cien metros de largo y cinco o seis de ancho, pero que ésta se destruyó pronto... Laercio, que es fundamentalmente un erudito y no un filósofo, admiraba sobre todo a Epicuro, como queda claro por el espacio que le dedicó. El libro final, el décimo de las Vidas de los filósofos ilustres, está enteramente dedicado a él, y eso no lo hace con ningún otro filósofo; por él conocemos la mayoría de los textos epicúreos (quedaría algo gracias a Cicerón o Séneca, pero nada más). Laercio los salvó del olvido excepcionalmente, tal vez porque pensó que su obra corría peligro. Sentía gran simpatía por ella, como lo prueba que concluya el libro proclamando que ese es el camino de la felicidad. La felicidad es la senda epicúrea. En cambio, Laercio era muy escéptico, aunque Epicuro no lo era, y eso se ve en muchas citas de tesis contrapuestas que da en la única historia de la filosofía antigua, la suya, que se ha salvado.

En Freud hay un principio del placer que está cerca del hedoné griego también. Recuerdo que una vez di una conferencia -que he perdido- sobre Freud y Epicuro, en donde subrayaba su modernidad. También está muy presente Epicuro en Nietzsche, éste habla con frecuencia de los pequeños placeres de la vida; y es 
que ambos fueron enfermos crónicos que conocían bien el dolor y sabían apreciar mejor ese placer sereno que consiste en la ausencia de sufrimiento... Freud me parece menos epicúreo, es más partidario de sacrificarse: su idea de sublimación lo refleja, o la de refrenar el placer para obtener una cultura digna. Me resulta mucho más trágico. Pero es que Freud, pese a todas las similitudes, resulta mucho más complejo porque los modernos han visto mucho más; los antiguos siempre son más sencillos, y atractivos.

Quizá Epicuro también lo pensara paralelamente en cierta forma, aunque no está en lo que queda de él. Pensemos en lo mucho que escribió: más de trescientas obras. Una persona que se pasa la vida escribiendo no es precisamente alguien que piense en la tranquilidad como fundamento de la vida. Otro tanto cabe decir en cuanto a su presunto egoísmo: su otro gran objetivo era la amistad, y esta idea tan epicúrea siempre supone un altruismo muy notable.

\section{¿Qué opinas de las críticas posteriores de Cicerón y Plutarco?}

A Plutarco le escandalizaba. No entendía que, cuando Epicuro localiza el placer en el vientre, venía a decir que no hay posibilidad de placer cuando se tiene hambre. Casi siempre le cita Plutarco para criticarlo, especialmente por su defensa del apartamiento de la vida pública y su necesidad de pasar desapercibido, el vive ocultamente. Aún poseía el sentido griego de que es fundamental ser un ciudadano comprometido con la vida política. La democracia auténtica, la griega, se basaba en esa colaboración del ciudadano en la asamblea y el voto; el teatro estaba asimismo hecho para todos. Esto no es muy moderno, pues muchos tienden hoy al repliegue silencioso (yo también me siento más a gusto así).

Tanto Cicerón como Plutarco eran gentes de orden, podríamos decir, y para ellos Epicuro resultaba subversivo. No porque fuera socialmente revolucionario, pues aconsejaba retirarse a la vida privada y desentenderse de las luchas políticas; pero hay algo egoísta en la defensa del placer. Por otra parte, su crítica a las ideologías que defienden el orden, la busca del poder y los grandes ideales, le convierten finalmente en alguien subversivo y revolucionario, aunque con sordina... Epicuro siempre fue muy calumniado. Los cristianos también vieron en él un gran enemigo, por su concepción de un Dios que no se interesa por los hombres. Modernamente, los pensadores y políticos conservadores, de rasgos muy platónicos, siempre rechazan el epicureísmo. La teoría platónica del poder y de una sociedad perfecta está en sus antípodas. Por el contrario, Epicuro está más cerca de Aristóteles en muchos puntos.

Parece que no te atrae mucho Plutarco, sobre todo sus Moralia.

Las biografías de Plutarco sí son magníficas. Las de Marco Antonio, la de César o la de Demetrio son extraordinarias; y me gustaría haberle traducido más. 
Las grandes frases de Shakespeare en Julio César y en Antonio y Cleopatra son de Plutarco, pues éste captó bien la visión trágica de la sociedad y de sus personajes; la misma Cleopatra es un ejemplo de ello. También me parece magnífico en cuanto transmisor de anécdotas. El estilo, en cambio, ya no es el de la época clásica; y a veces resulta un poco pesado.

Hablando de la tragedia, escribiste que el héroe elige su destrucción, y que «aunque el héroe hace lo que quiere, resulta que no quiere lo que hace». Esa ruina, esas consecuencias dolorosas y destructivas, ¿te atraen sobre todo poéticamente?

Me parecen hermosas poéticamente, quizá por la famosa frase de Heráclito acerca de que el destino de un hombre es su carácter. El héroe es un personaje con grandeza de carácter, tiene un ideal por el que arriesga la vida. Y la concepción trágica surge cuando la grandeza va unida a la catástrofe. Así la del Edipo de Sófocles que le lleva a la destrucción de sí mismo. Es una idea muy griega la de que los grandes personajes están expuestos a grandes riesgos, que la ruina se hubiera evitado si hubiesen sido más débiles de carácter. Antígona es arrastrada a la perdición por empeñarse en ser como es, y no ceder en nada. Los héroes de Sófocles no ceden nunca. Mueren de pie. En Eurípides, en cambio, los héroes están dispuestos a hacer algo por salvar la vida, y ya no son tales... La idea de que hay valores en la vida por los que merece la pena arriesgarse es propia de la Grecia antigua. Recordemos a Aquiles o a Sócrates, quien, paradójicamente, no deja de ser, él que quiso ser un sabio racional y feliz, un personaje trágico. Es la esencia del heroísmo, un ideal hoy devaluado, muy de otras épocas, pero muy digno.

Has trabajado sobre autores del siglo II de nuestra era, cuando se condensan muchos factores nuevos, se superponen muchas capas de conducta, no sin chirriar; el neoplatonismo va a robustecerse, el cristianismo está en el candelero, se hacen grandes recopilaciones de la medicina, de la astronomía, de todo el pensamiento.

El siglo II comienza siendo el de Adriano y también el de Epicteto, que defendía aún una forma de vivir entre sus discípulos, que era un filósofo practicante. Se inicia un tiempo confuso, de crisis, pero muy interesante donde, por un lado, se quiebran del todo las relaciones con el mundo antiguo, pues las ciudades ya no tienen autonomía en un vasto Imperio y la actividad como ciudadano es más superflua, pero al mismo tiempo hay una libertad de pensamiento y una universalización de las ideas que la hacen muy atractiva. Hay un renacimiento intelectual. Es también la época de expansión no sólo del cristianismo sino de los cultos mistéricos (el mitraísmo, el culto a Isis, etc.), de forma que era propio de entonces la busca de la salvación. Es un siglo donde el daimon se vuelve un lugar común, en 
SALUD MENTAL Y CULTURA

donde la idea de cosmos sufre avatares diversos, ampliándose o modificándose, pero donde se vive esa inseguridad que describió Dodds en Paganos y cristianos en una época de angustia.

Resumes esa tensión en tu prólogo a las Meditaciones: "La oposición entre el estoico, que basa su conducta en una razón divina, expresada en el daimon interior de la conciencia propia y reflejada en el orden cósmico, y el cristiano, adepto a una fe dogmática, era infranqueable». Éstos no se vincularan a las ideas de Marco Aurelio. Un siglo después las renuncias cristianas fueron del todo opuestas al mundo de éste, como estudió Peter Brown.

Me gusta una cita de Marco Aurelio, «La única defensa es no dejarse asimilar», pues si el hombre clásico estaba muy protegido por la ciudad, en el siglo II deja de estarlo del todo. En ese tiempo ser ciudadano de Roma ya era un valor universal (como hoy disponer de un pasaporte americano). La actitud espiritual de los cristianos es una visión sobre los humanos en la que se une audacia y masoquismo. En El cuerpo y la sociedad. Los cristianos y la renuncia sexual, Brown estudia de un modo impresionante la idea de continencia y la formación de un ideal ascético; ese desgarro que supone la sumisión del cuerpo lo vemos hoy como exótico. También lo estudió Aline Rousselle en Porneia. Del dominio del cuerpo a la privación sensorial, que centró en el período que va del siglo II al IV, centuria en la que el cambio se hará definitivo.

Publicaste también La interpretación de los sueños de Artemidoro, un libro muy curioso.

Sí, me interesó también mucho el libro de Artemidoro, del que yo sugerí la primera traducción al castellano (fue difundido en el siglo XVI, pero aquí nos llegó con unos siglos de retraso respecto a otras lenguas). Es un texto muy interesante del siglo II, que Freud utilizará en su gran estudio onirocrítico. Es una especie de manual de un profesional de la interpretación de los sueños, y resulta todavía muy atractivo por su simbología. En su tiempo, Artemidoro estaba considerado como un científico, y sintetiza muchas ideas naturalistas de entonces.

Los libros finales de Michel Foucault -El uso de los placeres y El cuidado de sí- llegan a esa época y en el segundo utilizó notablemente a Artemidoro.

A principios de los ochenta leí esa continuación de la Historia de la sexualidad de Foucault. Está en un punto intermedio entre la filología y la historia del pensamiento, y siempre fue muy curioso en sus lecturas médicas. Leí esos dos tomos finales con mucho aprecio y casi como una novela. Me gustaron mucho en la primera lectura; luego se me han perdido un poco, y más que una huella objetiva de lo que expuso queda el recuerdo placentero. No soy foucaultiano y sólo he 
leído de él lo que me interesaba: también Las palabras y las cosas, pero no otros estudios suyos. Eso sí, aprecio su estilo y su gran inteligencia, lo muchísimo que sabía y su modo impresionante de argumentar. En cambio, un Deleuze o un Lacan me resultan ajenos.

Dedicas tu reciente introducción a las Vidas de Laercio a la memoria de un papirólogo y maestro de filología griega y bizantina, Marcello Gigante.

Sí, tras la publicación de Los orígenes de la novela me invitaron primero a Bangor, en una universidad de Gales, a dar una conferencia; y luego Marcello Gigante me invitó a Nápoles a dar un par de conferencias, en español, sobre las novelas griegas, hacia 1980. Tuve amistad con este gran helenista de Nápoles, impulsor de los estudios de los papiros de Herculano en los setenta, y que murió en 2001. Este maestro de filólogos, que trabajó sobre Epicuro con brillante tesón, era una persona muy importante en Italia; fue una de las grandes figuras desaparecidas. Las que echamos de menos largo tiempo, como ahora a Vernant, desaparecido en 2007.

Siempre has hablado de Vernant, pero menos de sus amigos Detienne y VidalNaquet.

De Vernant me parece muy sugerente todo. Lamento mucho su muerte; un intelectual tan generoso y perspicaz como fue él es muy raro. A Vernant le conocí cuando estaba en Barcelona; y le invité a que viniera en el año 1975, pero murió Franco y se aplazó el viaje. Volví a llamarle cuando ya estaba en Madrid, en la UNED, hacia 1980. Dio entonces varias conferencias sin éxito de público. Una vez en mi despacho, donde se reunieron doce personas para oírle (entre ellas, Savater y Pollán). Estuvo cinco días, y dio otras charlas. Ahora tras su muerte organizamos un homenaje en la Fundación Pastor y creo que no reunimos más de veinte, de los cuales diez eran amigos míos. Ha influido poco en los filólogos españoles, con excepción de José Carlos Bermejo y Ana Iriarte; yo mismo he intentado recordar la honda vitalidad de sus estudios... Me entristece que no haya tenido aquí más influencia, quizá por su complejidad.

Tengo cartas de Detienne de los años setenta, y lo traté por entonces, en Barcelona y París. Lo leo siempre con gusto, aunque creo que ha ido perdiendo alguna profundidad crítica (La escritura de Orfeo, Comparar lo incomparable). Pero Los jardines de Adonis, de 1972, me parece el mejor ejemplo de análisis estructuralista; además no se limita al análisis de las formas sino que busca debajo de ellas las referencias históricas y sociales. Dentro de su tema tan definido, me parece ejemplar... De Vidal-Naquet admiro El cazador negro y sus artículos clásicos sobre la tragedia firmados con Vernant, y he reseñado El espejo roto, sobre el drama y la política clásicos; es curioso y personal su libro de divulgación, $E l$ mundo de Homero, de 2000. No he leído sus dos tomos de Memorias de finales de 
SALUD MENTAL Y CULTURA

los noventa ni su libro sobre el mundo judío. No le conocí personalmente, aunque creo, por quienes le trataron, que era una gran persona.

También están historiadoras de la Antigüedad como Nicole Loraux. Has escrito sobre la científica-mártir, Hipatia de Alejandría, sobre Casandra de Christa Wolf, sobre algunas mujeres anónimas. $Y$ destacaste la Historia de las mujeres (1992) de Michelle Perrot.

De esta brillante helenista, Nicole Loraux, muerta en 2003, aprecié mucho todos sus libros; incluso los menores, como Maneras trágicas de matar a una mujer, sobre las heroínas ante la muerte, o Madres en duelo sobre el llanto ante los hijos muertos. Me interesé, como decís, por el asesinato de la filósofa Hipatia. Y escribí un libro que me parece ameno y simpático, Audacias femeninas, donde resalto que, incluso en una sociedad tan machista como la antigua, siempre algunas mujeres aprovecharon las posibilidades de ser audaces y salirse del marco opresivo. Esa Historia de las mujeres es excelente por su enfoque y valiosa por su documentación histórica. Pero tengo la sensación de que los estudios al respecto han proliferado y se repiten mucho, a veces con visiones estrechas, pues si bien en el mundo griego la mujer fue silenciada y reducida a la servidumbre doméstica -quedaba excluida, injustamente, de la historia y de la gloria- lo sucedido allí acontecía en todo el mundo antiguo. No creo que se pueda hablar sin más, como se ha hecho, de la misoginia en Grecia. En el mundo árabe, por ejemplo, las mujeres han permanecido como estaban en Grecia hasta el siglo XIX; ahora han mejorado algo sin duda. No es un rasgo típico griego la misoginia, aunque las mujeres, como en todas partes por entonces, estuviesen condenadas a la carga doméstica y al silencio, había sus fiestas y puntos de fuga.

En la filosofía platónica y en la mitología las mujeres tienen un gran papel. También señalas que la literatura fue más justa con ellas que la realidad histórica.

Platón defendió la igualdad de inteligencias entre el hombre y la mujer, así como una educación idéntica para ambos. En el mundo de los dioses, las mujeres son tan brillantes y dignas de atención como los hombres, lo que sucede en pocas culturas. Es más, la patrona de la inteligencia es una diosa, Atenea; y es más inteligente que el dios de la guerra, Ares. Vernant estudió específicamente que si Ares es el dios de la guerra brutal, Atenea es la diosa de la guerra inteligente. Incluso aceptando que Atenea representa una feminidad recortada, el imaginario griego posee unas figuras femeninas como no las posee casi ninguna cultura, y solo aparecen en la cultura occidental mucho después... Personajes como Helena y Penélope, Antígona, Electra y Medea, o la Lisístrata de Aristófanes, expresan una idea muy digna de la inteligencia de la mujer. Su abundancia en la gran literatura griega supone un reconocimiento, pese a Pandora o a ciertos pasajes degradantes 
o burlones, donde se las animaliza. Existen figuras transgresoras magníficas, réplica acaso de la presencia de diosas en el panteón griego. Y está la pervivencia de una escritora de la categoría de Safo; pero, es verdad, ella está sola en la literatura.

\section{La posición de la mujer es, con todo, bastante especial.}

Medea adquiere valor de símbolo en Eurípides, se erige en portavoz de las desdichas de la condición de la mujer. Esas figuras tienen mucho de heroicas porque luchan contra el ambiente, y aún así logran sobresalir, mientras que la mujer en una sociedad como la árabe pudo conseguir mucho menos. Incluso en esa imagen recurrente que son las amazonas se observa cierto temor a ellas... Recuerdo haber escrito en un artículo que la mujer ha vivido en una situación de sometimiento tal que, para llegar a ser reconocida en su valor individual, tenía que dar un salto trágico. La gloria de la mujer provenía siempre, en el teatro trágico, de un acto negativo; la de los varones procede más bien de lo positivo. También es el caso de Clitemnestra o de Medea, por sus actos escandalosos, o el de la sublevación de Antígona. Se toleraba a la mujer como relativamente libre solo si aceptaba la sumisión. Y por ello su acceso a la gloria era trágico.

\section{La revolución de la mujer es uno de los logros más significativos.}

El progreso de la mujer es muy reciente. Incluso en las democracias contemporáneas, el voto femenino se implanta en el siglo XX. Pero el futuro intelectual está en las mujeres, en gran medida; y no sólo porque el número de universitarias sea mayor que el de los universitarios, es que creo que hacen muchas cosas con más delicadeza y más precisión que los varones.

Has escrito que la novela histórica es una «excursión sin riesgos» al pasado, aunque finalmente destacas más, por ejemplo, La muerte de Virgilio de Hermann Broch o Casandra de Christa Wolf. ¿No es ésta una literatura con riesgos?

José María Valverde me dijo una vez que a él no le gustaba nada la novela histórica, que la veía como una especie de trampa; hacer trampas es hablar de los antiguos con ideas modernas. No por eso evito esas novelas, yo las leo por placer. Antes leía hasta novelas aburridas, pero ahora he aprendido a dejarlas de lado... También las Memorias de Adriano de Yourcenar es un libro falso, pues le presenta como un personaje pascaliano. Al Yo, Claudio de Robert Graves le ocurre lo mismo. La lectura, por ejemplo, de Ivanhoe me descubrió el mundo medieval -la vida de entonces, cierta defensa social-, aunque reconozco que es un libro falso. Sin embargo, es curioso que en La novela histórica, ese gran libro de Lukács, hable muy bien del conservador Walter Scott, quizá porque supiese mucho de literatura. Tampoco los historiadores dominan la verdad de los hechos: Suetonio no había conocido a Claudio, y elegía a menudo lo pintoresco. 
SALUD MENTAL Y CULTURA

Ahora bien, acepto que en general es una literatura blanda frente a la otra, más dura o consistente, como es la tragedia a la que me refería antes. Pero las novelas históricas me hacen pensar... De autores españoles he leído algunas; a veces bizquean en exceso y tienden a la truculencia. Pero puedo citar algunas leídas hace poco que me han interesado. Como Genserico, de tema muy original, de un autor novel, Darío Varela, sobre ese rey de los vándalos. Poco sabemos de él, aunque dominó el Mediterráneo durante más de treinta años; y este documentado y fiel relato me ha ayudado a conocerlo. Otra novela actual, la del mexicano Gerardo Laveaga sobre Inocencio III -El sueño de Inocencio, editada en México, y pronto aquí- me ha hecho meditar sobre la figura de este gran papa que a la vez impulsó la Inquisición y aceptó la orden del revolucionario Francisco de Asís. Uno puede aprender mucho de esos relatos. Sin embargo, hay que leer una novela histórica como una novela, no como un libro de historia. Los Episodios nacionales son novelas. También lo es Guerra y paz... No me parecen históricas, en cambio, sino un ataque a la historia, todas las novelas mistéricas y pseudohistóricas que están ahora de moda. Son de un turbio atractivo, falsean lo histórico y atentan a lo verosímil.

\section{¿Qué te gustaría destacar finalmente?}

Que yo soy un traductor. Un tenaz traductor de textos clásicos y con afán filológico. Es decir, con amor a los grandes textos clásicos. Siempre me ha gustado mucho traducir a los grandes autores antiguos $-\mathrm{y}$ algún medieval-, y he elegido a los que me gustaban. Nunca lo he hecho por ganar dinero (poco se gana con ello); soy un profesor que traduce, además de comentar esos textos en mis clases. Afortunadamente no he necesitado vivir de mis traducciones. Y admiro a quienes practican profesionalmente ese oficio de la traducción, modesto y servicial. He buscado verter al castellano libros desconocidos aquí -el Pseudo Calístenes, Apolonio de Rodas, Calímaco y Crisórroe o los tratados hipocráticos- o que no se habían renovado: hasta mi versión reciente de Diógenes Laercio, solo existía una traducción, muy meritoria, de finales del siglo XVIII. Las obras muy traducidas suelen ser difíciles de mejorar. Me hubiera gustado traducir más textos, especialmente más Platón o más tragedia, y también dar una nueva versión de Marco Aurelio, que escribe un griego mezclado, a veces poco elegante (una versión es floja; otra, un poco áspera). No lo he hecho por falta de tiempo, y además por un cierto escrúpulo: no me gustan mucho las notas, que por cierto suelen hacerse copiándolas, y algunos textos requieren muchas anotaciones.

La traducción me ayuda a leer y a repensar las cosas. Un traductor debe ser, primero, un buen lector. Una versión nunca es exacta, introduce matices y desajustes, y hay que revisar los textos de continuo; así que resulta un estimulante 
ejercicio personal, una gimnasia intelectual. He traducido obras que me gustaba comprender y reinterpretar. Sin olvidar que, aunque humilde y servicial, el traductor también debe esmerarse en ser -por lealtad al mensaje clásico-, un buen escritor.

\author{
F. Colina y M. Jalón
}

\title{
BIBLIOGRAFÍA
}

Su trabajo filológico inicial fue El sistema diatético en el verbo griego (Madrid, CSIC, 1970). Complementario a este tipo de estudio son sus introducciones o versiones (a veces las dos cosas): Pseudo Calístenes, Vida y hazañas de Alejandro de Macedonia (1977), con el que se abrió la Biblioteca Clásica Gredos; Jenofonte, Anábasis (1978); Platón, Laques, Protágoras y Fedón (1981 y 1986); Aristóteles, Política e Investigación sobre los animales (1977 y 1992); el prólogo a las Fábulas de Esopo (1978); Eurípides, Fenicias, Orestes, Infigenia en Áulide y Bacantes; Marco Aurelio, Meditaciones (1977); Caritón de Afrodisias, Quéreas y Calírroe (1979); Antología de la poesía lírica griega (Alianza, 1980); Calímaco y Crisórroe (1982); Apolonio de Rodas, El viaje de los argonautas (1983); Tratados hipocráticos (1983), de los que tradujo «Sobre la ciencia médica», «Sobre el médico», «El pronóstico», «Sobre la enfermedad sagrada», «Sobre la dieta». Recientemente han aparecido versiones suyas de la Odisea (2004) y de D. Laercio, Vidas y opiniones de los filósofos ilustres (2007), ambas en Alianza.

Pero vayamos a sus libros. Los orígenes de la novela (Istmo, 1972; 1992), y Primeras novelas europeas (Istmo, 1974; 1988), describen las vicisitudes del relato. Las obras Prometeo, mito y tragedia (Hiperión, 1979; 1994), Epicuro (Alianza, 1981; 2002); Mitos, viajes y héroes (Taurus, 1981; Punto de Lectura, 2001); La secta del perro (Alianza, 1987; 2007), que es su larga introducción a la Vida de los filósofos cínicos, están centrados en el mundo griego. Pero asimismo escribe la Historia del rey Arturo y de los nobles y errantes caballeros de la tabla redonda. Análisis de un mito literario (Alianza, 1983; 2003), o Lecturas y fantasías medievales (Mondadori, 1990), El redescubrimiento de la sensibilidad en el siglo XII (Akal, 1997). Sus trabajos sobre el ámbito mitológico son: La mitología. Interpretaciones del pensamiento mítico (Montesinos, 1987; Literatura y ciencia, 1997), Introducción a la mitología griega (Alianza, 1992; 2007, ampliada), y Diccionario de mitos (Planeta, 1997; Siglo XXI, 2004).

Y otros escritos suyos, todavía no citados: Los siete sabios, y tres más (Alianza, 1989, 2007); Figuras helénicas y géneros literarios (Mondadori, 1991); Audacias femeninas (Nerea, 1991; Círculo de Lectores, 1993); El zorro y el cuervo (Alianza, 1995); La Antigüedad novelada. Las novelas históricas sobre el mundo griego y romano (Anagrama, 1995); Sobre el descrédito de la literatura y otros avisos humanistas (Península, 1999); Apología de la novela histórica (Península, 2002); Viajes a la Luna: de la fantasía a la ciencia ficción (ELR, 2005); Historia, novela y tragedia (Alianza, 2006). 